\title{
Institutionalized Normality and Individual Living Situations. The Non-Take-Up of Old-Age Basic Income Support in Germany
}

\author{
Felix Wilke*
}

\begin{abstract}
The study analyzes the non-take-up of means-tested benefits among older people in Germany using GSOEP (2010-2015). The results suggest that 6 out of 10 do not claim benefits. To explain non-take-up the study looks at differences between individual living situations and institutionalized normality. The empirical section deals with three dimensions of the living situation: coping with financial hardship, acknowledgment of previous achievements, and temporal dynamics. While coping and temporal dynamics prove to be relevant, the results regarding acknowledgment are mixed.
\end{abstract}

Keywords: Social policy, non-take-up, old-age security, poverty, social security, welfare

\section{Institutionelle Normalitätsvorstellungen und individuelle Lebenssituationen. Die Nichtinanspruchnahme der Grundsicherung im Alter in Deutschland}

Zusammenfassung: Untersucht wird die Nichtinanspruchnahme der Grundsicherung im Alter in Deutschland mit dem SOEP (2010-2015). Gezeigt wird, dass 6 von 10 keine Leistungen beantragen. Zur Erklärung werden Unterschiede zwischen der individuellen Lebenssituation und institutionellen Normalitätsvorstellungen herangezogen. Die Empirie fokussiert drei Dimensionen: das Zurechtkommen mit schwierigen finanziellen Bedingungen (coping), die Anerkennung früherer Leistungen und zeitliche Veränderungsdynamiken. Coping und Veränderungsdynamiken erweisen sich als wichtige Einflussfaktoren. Die Befunde zur Rolle von Anerkennung sind nicht eindeutig.

Schlüsselwörter: Sozialpolitik, Nichtinanspruchnahme, Alterssicherung, Armut, Soziale Sicherung

\section{Idées institutionnelles de normalité et situations de vie individuelles. La non- utilisation de la prestation vieillesse de base en Allemagne}

Résumé: Cette étude examine la non-utilisation de l'offre de base pour la vieillesse en Allemagne pour les années 2010-2015, en se concentrant sur les différences entre les situations de vie individuelles et la normalité institutionnelle. L'étude empirique se concentre sur trois dimensions: la gestion des conditions financières difficiles (coping), la reconnaissance des réalisations antérieures et la dynamique du changement dans le temps. Les dynamiques d'adaptation et de changement sont des facteurs d'influence très importants. Les conclusions sur le rôle de la reconnaissance ne sont pas claires.

Mots-clés: Politique sociale, non-recours, système de retraite, pauvreté, sécurité sociale

Department of Social Work, University of Applied Sciences Jena, D-07745 Jena, felix.wilke@ eah-jena.de 
Non-take-up i.e. the "non-receipt of benefits by people who are entitled to them" (Dubois and Ludwinek 2015, 5) has not been of major interest in the social policy debate so far. However, there is broad evidence that non-take-up occurs in different institutional contexts and across a wide range of social systems (Currie 2006; van Mechelen and Janssens 2017; Bruckmeier and Wiemers 2018). Surprisingly, the empirical analyses show that the number of people that do not claim benefits is often higher than the number of people receiving them (Hernanz et al. 2004; Dubois and Ludwinek 2015).

There are several explanations of why people do not claim their benefits (van Mechelen and Janssens 2017). Empirical studies have put forward different explanations to understand non-take-up better, but at the same time important questions remain unanswered (section 2). As I am going to argue, existing approaches share one common problem: they narrow down the set of motives and incentives that guide peoples' actions, thereby neglecting key aspects of the phenomenon. With a broader perspective (section 3), I am going to analyze non-take-up from a relational perspective between institutionally defined normality and individual living situations (Vobruba 2000). The empirical part of this article (section 4) will look at individual living situations, motives, and strategies of older people in Germany who do not claim old-age basic income support (Grundsicherung im Alter). I will use new results from an extensive microsimulation of retired households in Germany for 2010-2015. The study shows that non-take-up is common among older households. A systematic comparison of households with and without take-up reveals important factors apart from the ones already considered like financial incentives, stigma, and possible information costs (e.g. Currie 2006). The study focuses on coping strategies regarding material deprivation, attitudinal differences, and long-term strategies of overcoming social assistance.

\section{Theoretical Approaches and Quantitative Findings}

Most studies on non-take-up use a quantitative design based on extensive simulation models. These models incorporate eligibility criteria defined by law to determine who could get welfare benefits. The simulated results are compared to the answers given in the survey to check whether the respondents receive benefits. The fraction of people not claiming benefits in contrast to all eligible people is defined as the rate of non-take-up. There are three major sources of error when modeling non-take-up:

1 I would like to thank the two anonymous reviewers, Tim Deeken and Matthias Römer for their helpful suggestions and comments. I also would like to thank Peter Haan and his colleagues for allowing me to use the results of the microsimulation study. 
missing information in the survey, a wrong specification of the model, and missing/wrong answers of the respondents (Bruckmeier et al. 2020). Therefore, most simulations model different scenarios. Despite considerable uncertainty about the exact amount of non-take-up, there is a broad consensus that non-take-up is quite common. A wide range of studies shows that non-take-up occurs in very different welfare systems and countries (Dubois and Ludwinek 2015). It also seems to be consistent over time (Hernanz et al. 2004). There is evidence that non-take-up is more widespread in means-tested welfare schemes (van Mechelen and Janssens 2017). In these schemes, non-take-up rates often exceed $50 \%$. Simulations suggest that people waive a considerable amount of money. Regarding old-age basic income support in Germany, only one previous study exists. Becker (2012) estimates with data from 2007 that the rate of non-take-up is about $60 \%$ for retirees. On average they forego benefits worth $100 €$ per month, which is a comparatively high amount compared to median pension income of $650 €$ in this group (Becker 2012).

Various aspects are discussed why people do not claim benefits (overview: Currie 2006; van Mechelen and Janssens 2017). Usually, studies focus on problems of knowledge/information, process costs, and stigma. For example, among those who do not claim the French minimum income benefits, $68 \%$ of the people lack knowledge of the benefit (Dubois and Ludwinek 2015, 18). Mika and Bieber (2006) report that social assistance in Germany often is not claimed because people assume that benefits would have to be repaid later. Concerning education as a proxy for knowledge and information, studies found mixed results. While some studies show higher rates of non-take-up for less educated people (e. g. Frick and Groh-Samberg 2007; Buslei et al. 2019), others do not confirm this result (Riphahn 2001). They also show that small programs have higher rates of non-take-up (van Oorschot 2002), because people may not be aware of the existence of the program. Another factor closely linked to knowledge is complexity (Dubois and Ludwinek 2015, 25-26; van Mechelen and Janssens 2017, 8-11). It is argued that complex procedures and comprehensive eligibility criteria increase the amount of information required and thereby result in non-take-up (van Mechelen and Janssens 2017).

\subsection{Rational Choice Explanations}

The theoretical mechanism behind the observed non-take-up of benefits is often modeled within a rational choice framework (Riphahn 2001; Currie 2006). In these models, gathering information and the application process are important cost factors that might outweigh the potential benefits. Rational choice models can explain the lower level of take-up among those who waive a low amount of money (Riphahn 2001; Whelan 2010; Bruckmeier and Wiemers 2018).

Despite the intuitive logic, there are several reasons why a rational choice approach can only partially explain the problem. First, a large fraction of people do not claim benefits. This fact raises serious doubts about the logic of the argument 
because a straightforward rational choice approach (with no information costs) would suggest full take-up. Since most studies do not measure information costs directly, there is a serious risk to immunize the theory from falsification. Without a thorough measure of information costs, every potential behavior could be defined as an outcome of a rational choice, which makes the theory tautological. Second, it remains unclear whether a lack of knowledge is the cause or already part of the phenomenon to be explained. For example, it does not make much sense to get to know a program in detail if you are not planning to use it anyway. The threshold model by Kerr (1982) and van Oorschot (1998) at least suggest such a line of argument (see also: Neuenschwander et al. 2012). Third, the rational choice models usually applied focus on short-term financial incentives (similar: Vobruba 2000, 95-96). Thereby they ignore the diversity of individual living situations and neglect different motives for action in the short- and long-term.

Some scholars have extended the rational choice model by integrating nonfinancial motives. The most prominent example is Moffitt (1983), who models stigma as a cost that lowers the marginal utility of welfare income. Following this line of argument, every potential mechanism can be conceptualized in terms of costs and benefits. While such a model covers more motives, it becomes fuzzier at the same time and thereby compounds the aforementioned problems.

\subsection{Stigma Approaches}

One of the motives besides financial incentives is prominently discussed as stigma (e. g. Hümbelin 2019). According to the basic idea, people do not claim benefits because "feelings of dependency and a sense of inferiority" arise out of claiming (Blomberg and Peterson 2017, 163). Referring to Goffman (1990), it is argued that the stigma-inducing element (welfare benefits) is linked to a whole chain of other characteristics that contradict commonly shared norms and values (Engelhardt 2010, 130). People receiving benefits are classified as lazy, unsuccessful, and deliberately living off someone else's pocket (Bullock et al. 2001). While the stigma-related literature discusses a wide range of aspects, it is primarily concerned with stigma as a form of social control by others. The stigma-related thesis proposes that people refuse to claim benefits more often if take-up can be observed by others. Therefore, non-take-up should occur especially in dense social relationships (Kayser and Frick 2001). These studies assume non-take-up would be more common in rural areas or among people in religious communities which are used as proxies for dense social relationships (Kayser and Frick 2001). A more sophisticated proxy for stigma has been applied in a recent study by Hümbelin (2019). He shows that regions in Switzerland with a more left-wing (welfare-friendly) behavior also show higher take-up rates of social assistance. Few studies do explicitly explore the feelings of shame and stigma associated with social benefits (e. g. Neuenschwander et al. 2012; Baumberg 2016; Gurr and Jungbauer-Gans 2017). Using a survey from the UK, 
Baumberg (2016) can show that some benefits are indeed associated with stigma and therefore hamper take-up.

In contrast, other authors are more cautious when it comes to stigma. After an extensive review of the literature Currie (2006) sees no compelling empirical evidence to support the stigma hypothesis. She states that there are major identification problems. To unveil the difficulties of stigma related approaches to explain non-take-up, I will take a closer look at the source and a target of stigma. About the source, with general society/media, close families/circles of friends, or municipal officials different "broadcasters" of stigma exist. Although the distinction between these realms has important conceptual consequences for non-take-up, empirical studies hardly distinguish between them. For example, the pattern of non-take-up should be different whether a person is stigmatized by its family or by a gatekeeper. Also, research on stigma is primarily concerned about the visible forms of stigma. Thereby, the internalization of values and norms elaborated in various social theories like shame (Goffman 1990; Elias 2013, 323-420) are left out. If internalization is considered, non-take-up may occur even if the behavior cannot be observed by others, because it contradicts the individual's identity. In this case, social exposure would not be a suitable way to measure stigma.

Regarding the target of stigmatization, most studies refer to the benefit recipients. This may be useful as an empirical approximation in some cases but might miss important aspects. The German sociologist Georg Simmel (2009[1908], 439) argues that social support may initiate a process of social attribution that includes stigmatization, but the relevant social classification is poverty. Because of Simmel's analysis, we should be aware that beyond welfare benefits, poverty as such may be a matter for stigmatization as well. Poverty research has shown that experiences of exclusion and stigma occur regardless of getting social assistance (Walker 2014). Hence, stigmatization is unlikely to disappear if a person does not claim benefits (Becker and Gulyas 2012).

In summary, both rational choice and stigma approaches have made important contributions explaining the phenomenon of non-take-up. At the same time, however, the way they are implemented in quantitative studies narrows down the focus of people's motives and strategies. From a methodological point of view, this is especially problematic since the quantitative material usually gives little information as to whether financial incentive structures or stigmatization experiences are guiding the action.

\section{A Relational Perspective}

The discussion about the theoretical underpinning of current research regarding non-take-up suggests that the phenomenon should be looked at more generally. 
Therefore, I suggest a theoretical approach that is open to different motives and strategies of people beyond financial incentives and stigma. As a starting point, the setting of non-take-up must be analyzed. Social security entitlements are codified by law and conveyed by institutions. Non-take-up is a specific behavior that takes place in relation to institutions. Hence, it must be examined in relation to those institutions (Vobruba 2000, 108). On one side of the relation, different individual living situations can be observed. They include a variety of material situations, social contexts, and different motives - financial incentives and the fear of stigma amongst them. On the other side of the relation, there are institutional rules. Research so far has analyzed institutional aspects mainly as administrative hurdles increasing individual costs for claiming benefits (van Oorschot 1998; Neuenschwander et al. 2012). ${ }^{2}$ According to Vobruba (2000, 104-121), the legal system does not only codify the law but also creates a certain standard of normality (which differs from "empirical normalities"). The law defines certain typified cases that are regarded as systemconforming. This point of view implies that a welfare scheme is often conditional on a behavioral adaption. Scholars like Offe argue that the contradiction between institutional norms and individual living situations are systematically created. Following Offe (1984), social policy is at the same time an alien and disruptive element in capitalistic societies and a necessity for the reproduction of the capitalist system. It must be ensured that the social welfare system "should be used, but it should not be used extensively" (Blomberg and Peterson 2017, 167). Offe argues that restrictive access control and subsequent control are necessary elements to make an off-the-job life unattractive. Their function is to guarantee the priority of the labor market. This is of importance for social assistance, which is unconditional of labor market participation. Hence, "claimants are not only endowed with money, but are drawn into relations of 'treatment" (Offe 1984, 111). This institutional aspect of nontake-up has been largely neglected so far. One of the few empirical studies dealing with the organizational and normative barriers to means-tested benefits has been conducted by Bertrand et al. (2006, 16-18). They show the "hassle" that various US service programs produce by systematically introducing high complexity, threats of punishment, and tight deadlines into different welfare schemes. They also show that these institutional barriers have a highly deterrent effect on the usage of a program.

Regarding the old-age basic income support in Germany, which serves as the empirical case study, the institutional structure of this benefit system is complex. The old-age basic income support in Germany is a means-tested social benefit for people at risk of poverty in old age (and in case of reduced earning capacity - which will be ignored in this study). In 2004, it was separated from the general social assistance (Sozialhilfe) in Germany (Becker 2012, 126) to reduce possible problems

2 Several research projects currently conducted in Belgium focus in-depth on how administrative rules and local authorities influence the take-up of means-tested benefits (see for example: van Lancker et al. 2020). 
of stigmatization and simplify the conditions to gain access (e.g. simpler application forms, no recourse is made to children). It guarantees a minimum income including a benefit standardized on the federal level (in 2021: $446 €$ for a single household), additional housing costs, and in some cases additional needs.

Social law describes very precisely which group of people needs assistance, which resources are considered and how resources must be used. It also defines how individuals should behave while receiving benefits and how prior achievements (e. g. assets and pensions entitlements) are acknowledged (see Kaltenborn 2019 for the conditions defined by social law). These rules and their underlying normative ideas will be called institutionalized standards of normality. The standardized benefit is determined based on statistical averages of expenses of lower-income groups measured in surveys. In deviation from this statistical approach, however, several consumer goods have been excluded ex-post as they are not considered to be necessary or normatively desirable (e.g. tobacco, indoor plants). ${ }^{3}$ In addition to the standardized calculation of need, individual needs are also considered to a certain extent (most importantly: housing costs and health costs). Total assets above $5000 €$ are not allowed. The possession of a car can also be a hindrance to access because it would be classified as an asset. Resources are mainly defined as financial resources (income and assets). Their usage is obligatory. Every individual must check whether financial resources from other social systems (e. g. housing assistance) could be used before applying for old-age basic income support. This can lead to complex application procedures with different authorities. While family resources have been partially excluded from old-age basic income support, the income of a partner still must be considered, as well as children's income above $100000 €$ per year. Recipients have to confirm their financial situation in follow-up applications every year. If the financial situation changes, benefits will be adjusted. The institutional rules also suggest a certain behavioral orientation for the future. There is a disincentive to save while receiving benefits. Other rules restrict the duration and location of vacations. Regarding the entitlements and financial assets acquired over the life-course, the social assistance scheme implies a devaluation - since accumulated entitlements are counted against benefits (with exceptions).

The overview given above shows that a "gap between the institutionalized standards of normality and real living conditions" (Vobruba 2002, 606) should be expected. In order to receive benefits, individuals have to adapt to the formal rules and to the implicit notion of normality. Consequently, non-take-up has to be expected to a certain extent. The larger the necessary adjustment processes are the less likely a person will claim benefits. To investigate this hypothesis empirically, I will focus on three dimensions of relevant differences between institutionalized

3 The normative implications of this calculation of need have been extensively described and criticized elsewhere (Becker 2016). 
standards of normality and individual living situations: coping, acknowledgment, and temporal perspective (CAT).

Coping addresses the way people deal with limited resources. I expect people to forego benefits more often if they can cope with limited financial resources because they perceive less pressure to adapt to institutionalized standards of normality. For example, old-age research has shown that the elderly often have a comparatively low standard of living especially regarding their facilities, while at the same time being quite satisfied with their situation (Voges und Zinke 2010). The ability to get along with low financial resources can be the result of long-term experiences as well as a short-term adaptation process. ${ }^{4}$

Acknowledgment refers to the gap between institutionalized standards of normality and individual attitudes towards previous achievements. I argue that the fear of being stigmatized is just one aspect of a wide variety of attitudinal dispositions. Another important dimension concerns the underlying norms in different social security schemes, with meritocratic norms of insurance-based social systems versus norms of social assistance in means-tested systems. People with long working careers should refrain from using means-tested benefits that do not value their previous achievements.

Third, concerning the temporal structuring of action, it is assumed that people do not claim benefits if the status of neediness is classified as only temporary. The research on the dynamic of social assistance has demonstrated that the receipt of benefits from means-tested benefits usually ends after a short time (Saraceno 2002). For non-take-up, this means: In case of foreseeable changes of the financial situation applying for benefits may be less attractive. ${ }^{5}$

\section{$4 \quad$ Empirical Part}

\subsection{Data and Method}

The following analysis is based on data of the German Socioeconomic Panel (GSOEP), which is a representative panel survey of households and their members in Germany (Goebel et al. 2019). In this study, I use the waves 2011-2016 and confine the sample to households with the youngest person being 65 years and older. In each wave, about 3,000 households meet this criterion. Old-age basic income support is part of the household questionnaire - with households being asked whether they received benefits in the last year. Hence, the analysis focuses on old-age basic income support for the years 2010-2015. Although the simulation is

4 A comparable line of argument can be found in discussions on bounded rationality. The concept of satisficing from Simon (1997), may also suggest that people do not take-up when they get along. To my knowledge, Simon's concept has not been applied in non-take-up research. 
conducted on the household level, personal characteristics are important to investigate (i. e.: gender). In GSOEP, each household member receives an additional personal questionnaire. In single households, this information can be used straightforward. In non-single households, only the information of the head of household, who fills in the household questionnaire, will be used. GSOEP defines the head of the household as the person who is best informed about the overall household situation. The eligibility for benefits has been modeled on the household level using the DIW microsimulation model STSM (Steiner et al. 2012). In a recent study, Buslei et al. (2019) specified STSM to simulate old-age basic income support. Thanks to the authors I was able to use the microsimulation results for further investigation. The STSM model simulates the tax system and social contributions as well as all significant social transfers in Germany of the household and its members respectively (Buslei et al. 2019, 7). The researchers calculated the household need based on the standardized benefit, additional individual benefits, and housing costs. Thresholds for housing costs defined by social law have been inferred from the housing costs of all lower-income households in GSOEP for different regions. Financial resources of a household are based on extensive information about different income sources given by the respondents like labor income, income from self-employment, income from public private and occupational pensions, income from rent and welfare benefits. Unfortunately, the GSOEP does not include information on assets regularly. However, the microsimulation uses the annual information from respondents about their income from interest, dividends, and profits. Information on asset income was used to derive financial assets based on the assumption of a $2 \%$ interest rate - which means, all respondents reporting more than $100 €$ annual income from assets have been classified as non-eligible. Although the assumption of $2 \%$ may be too high, the implications for the results presented below are negligible. ${ }^{6}$ Furthermore, the financial value of material assets (i. e. car) was considered. To rule out inaccuracies of the simulation model, eligibility is assumed only if a household could claim at least $20 €$ per month.

Since there is no official statistics on non-take-up of old-age basic income support in Germany the reliability of the data and corresponding simulation needs to be assessed indirectly. One way is to compare the rate of non-take-up to previous studies. Becker (2012) calculated a non-take-up rate of $60 \%$ based on SOEP Data for the year 2007 which matches the results presented here (see table 1 below). Notably, Becker was able to directly check for assets which had been included in the

6 Only $13 \%$ of the non-take-up households report to have any income from assets. An underreporting of lump-sum payments from private pensions is possible. However, the most common private pension scheme (Riester-Rente) is not widespread among elderly people (Wilke 2016, 239). In a sensitivity analysis, all households with more than $50 €$ asset income per year were classified as non-eligible (assuming $1 \%$ interest rate). In 17 cases this results in non-eligibility. The quantitative results remain unchanged in a lower interest rate scenario and are available on request. 
2007 survey. Another way to measure the quality of the simulation is the beta error (Frick and Groh-Samberg 2007), which occurs when a respondent states that she/ he has claimed benefits, but the simulation classifies her/him as not eligible. The beta error of the simulation used is $25 \%$ (Buslei et al 2019, 27; other studies report beta errors between $15 \%$ and $20 \%$ - see Harnisch 2019, 12-13). This number gives an impression about insecurities in the micro-simulation, but also about potential underestimations of non-take-up due to strong eligibility assumptions. Another problem has been discussed by Bruckmeier et al. (2020). They compared survey answers with administrative data and show that there is a tendency to underreport the actual take-up of unemployment benefits. They suggest that non-take-up rates may be overestimated by 5 percentage points. Unfortunately, comparable analysis of old-age basic income support does not exist.

A detailed description of the simulation of non-take-up of old-age basic income support and the variation in different scenarios can be found in Buslei et al. (2019). Using the microsimulation model, the group of households in retirement can be divided into three subgroups: non-eligible households, recipients, and nontake-up households.

\subsection{Empirical Findings}

Table 1 summarizes the occurrence of take-up and non-take-up for different socioeconomic parameters. Due to the small number of eligible households, the analysis is based on the pooled sample. The prevalence of old-age basic income support in the weighted survey $(2.88 \%)$ is comparable to official statistics (in 2015:3.2\% see Kaltenborn 2019). The non-take-up rate (59\%) indicates that six out of ten eligible households do not claim benefits. This confirms the (empirical) normality of non-take-up for older people in Germany. The simulated amount that could be claimed is considerable (not shown in table). Most households give up on between $100 €$ per month ( $1^{\text {st }}$ quartile) and $300 €$ per month ( $3^{\text {rd }}$ quartile).

The share of people receiving benefits is almost equal in the Eastern and Western part of Germany. At the same time, non-take-up can be observed significantly more often in Western Germany (4.71\%) than in the former GDR (2.19\%). Potential reasons for these differences are hard to grasp and would need further investigation. They could be related to differences in the composition of both groups or they could reflect experiences of the post-socialist transformation in Eastern Germany. The table also shows that non-take-up is more common among women, those age 75 and above, and the less educated. Among single person households, non-take-up as well as the receipt of benefit is more prevalent than in other households. While the table gives the first impression about social structure, it says little about the reasons for non-take-up.

Table 2 takes a closer look at the living situation of retired households. Group-specific averages and percentages are shown for each of the three groups: 
Table $1 \quad$ Description of old-age basic income support and Non-take-up

\begin{tabular}{|c|c|c|c|c|}
\hline Characteristic & $\begin{array}{r}\text { share of recipients } \\
(\%)\end{array}$ & $\begin{array}{r}\text { share of non-take-up } \\
(\%)\end{array}$ & $\begin{array}{r}\text { rate of non-take-up } \\
(\%)\end{array}$ & $\mathrm{N}$ (entitled) \\
\hline All & 2.88 & 4.18 & 59.21 & 1297 \\
\hline \multicolumn{5}{|l|}{ Region } \\
\hline west & 2.90 & 4.71 & 61.84 & 1107 \\
\hline east & 2.77 & 2.19 & 44.16 & 190 \\
\hline \multicolumn{5}{|l|}{ Gender } \\
\hline male & 2.64 & 2.46 & 48.24 & 454 \\
\hline female & 3.09 & 5.79 & 65.18 & 843 \\
\hline \multicolumn{5}{|c|}{ Size of household } \\
\hline 1 & 3.61 & 5.39 & 59.90 & 1015 \\
\hline more than 1 & 1.71 & 2.26 & 56.91 & 282 \\
\hline \multicolumn{5}{|l|}{ Age } \\
\hline $65-69$ & 5.82 & 3.98 & 40.60 & 298 \\
\hline $70-74$ & 3.08 & 3.08 & 50.04 & 301 \\
\hline $75-80$ & 1.79 & 4.93 & 73.43 & 330 \\
\hline$>80$ & 2.03 & 4.68 & 69.73 & 366 \\
\hline \multicolumn{5}{|l|}{ Education } \\
\hline low & 3.64 & 7.30 & 66.74 & 381 \\
\hline medium & 2.47 & 3.80 & 60.60 & 633 \\
\hline high & 2.21 & 1.97 & 47.07 & 192 \\
\hline
\end{tabular}

Note: GSOEP 2011-2016, pooled data; results weighted; gender, age, and education refer to head of household; education low = ISCED 1/2 (up to general elementary), medium = ISCED 3/4 (up to post-secondary non-tertiary education), high = ISCED 5/6 (at least some form of tertiary education).

non-eligible, recipients, and non-take-up. ${ }^{7}$ The table shows that the group of non-eligible is far better off regarding its material and social situation than the two groups of eligible households (take-up and non-take-up). For example, the household income of those not entitled is on average twice the income of eligible households. ${ }^{8}$ The low income of eligible households is associated with severe material deprivation and a lower assessment of the social situation. More than $30 \%$ of the eligible households perceive their rent as being a high burden - with only minor differences between the group of recipients and the group of non-take-up. The majority of eligible households do not go on vacation regularly and do not replace old furniture. The degree of material deprivation seems quite similar among take-up and non-take-

$7 \quad$ Some variables are not included in the survey on a regular basis. Gaps have been imputed by household specific averages. The advantage of this imputation procedure is that the entire group size can be used. However, the imputation draws on the assumption that there is stability over time. Information about variables with gaps can be found in the table remarks.

8 Although non-eligible households are larger on average (results of additional analysis not shown here, but available from the author on request). 
Table 2

Description of the living situation among older households

\begin{tabular}{lrrr}
\hline & not-entitled & recipients & non-take-up \\
\hline Financial situation & & & \\
Net Income HH in $€$ & 1840 & 984 & 955 \\
Statutory Pension in $€$ & 1287 & 555 & 673 \\
Material deprivation & & & \\
Rent in $€$ (excl. heating costs) & 448 & 353 & 420 \\
\% rent is high burden & 16.06 & 32.44 & 31.47 \\
Satisfaction dwelling (0-10 high)* & 8.18 & 7.27 & 7.73 \\
\% no yearly vacation & 44.98 & 80.26 & 70.21 \\
$\ldots$ \% for financial reasons & 12.04 & 63.68 & 46.62 \\
\% no replacement old furniture & 56.31 & 84.08 & 72.84 \\
$\ldots$ \% for financial reasons & 12.11 & 59.63 & 40.69 \\
\% no reserves for financial emergencies & 12.56 & 78.09 & 49.26 \\
Satisfaction income (0-10 high)* & 6.97 & 4.26 & 5.13 \\
\% worried about own finances* & 9.93 & 29.73 & 26.43 \\
Employment history and work ethic & & & \\
Years in employment* & 33.13 & 31.29 & 27.49 \\
Years in unemployment* & 0.68 & 4.65 & 1.81 \\
\% exp. with means-tested benefits & 2.41 & 27.46 & 8.33 \\
Achievement orientation (0-7 high) & 6.01 & 5.82 & 5.86 \\
Social situation & & & \\
\% no neighbor contact & 17.54 & 33.02 & 31.40 \\
\% socially isolated* & 12.06 & 35.80 & 23.99 \\
Appreciation of activities (0-10 high)* & 6.83 & 5.60 & 6.26 \\
Satisfaction life (0-10 high)* & 7.11 & 6.02 & 6.37 \\
\hline
\end{tabular}

Note: GSOEP 2011-2016, pooled data; results weighted; variables with * represent individual answers from the head of household; variables with gaps: vacation/replacement of old furniture; burden of rent, social isolation, appreciation of activities, neighbor contact; variable definitions: net income $=$ sum of household income including welfare benefits, statutory pension = sum of own and dependent's pension, rent is high burden = share of sample stating rent is "high financial burden" (other options: low financial burden, no problem), no neighbor contact $=$ share of sample with loose or no neighbor contact, socially isolated = share of households sometimes/ often/very often feeling socially isolated (other options: seldom/never), exp. with means tested benefits $=$ at least one episode of basic income support for unemployed (ALG II) between 2005 and 2014, achievement orientation = "You must work hard to achieve success", appreciation = "Do you feel that what you are doing in your life is valuable and useful?"

up households. However, there is a notable difference. The financial stress is less strongly perceived as such among the group of non-take-up. For example, a large proportion of non-take-up households do not take a vacation regularly (70\%) but at the same time, they do not attribute this to financial reasons ( $47 \%)$ compared to households receiving benefits (64\%). Other indicators, such as the purchase of new furniture, confirm this impression. The indicator of income satisfaction reveals a 
similar pattern: Non-take-up households perceive comparably less financial pressure while living in material shortage. They are more satisfied with their income and less worried about their financial situation. Since the simulation model uses a proxy to take wealth into account, the results confirm that coping plays an important role in non-take-up and does not just reflect different wealth positions.

The next question is whether benefits are not claimed because previous achievements during the career would not be acknowledged. The results regarding this question are ambiguous, depending on the indicators used. One way to measure the importance of previous achievements is to look at the entitlements of the statutory pension insurance. The statutory pension insurance is based on the equivalence principle. A higher pension reflects higher contributions during the life-course. In contrast, the benefits of old-age basic income support are equal for people with high entitlements compared to those with low entitlements. ${ }^{9}$ Thus, it can be assumed that non-take-up is more widespread among those with a strong connection to an entitlement-based system. The hypothesis is supported by the fact that non-take-up households receive a large amount of money from the statutory pension. Notably, these households do not necessarily have longer periods of employment, as shown by the cumulative length of employment over the life-cycle. ${ }^{10}$ Another way to grasp the dimension of acknowledgment is to look at the attitudinal level. It is assumed that people who identify themselves with a meritocratic society are less eager to take-up means-tested benefits. The achievement-orientation is measured as the extent to which a person agrees that success is based on hard work. In contrast to the theoretical proposition, there is almost no difference between households with and without take-up. Remarkably, unemployment experiences - particularly the means-tested basic income support for unemployed (ALG II) - are rarely among the group of households with non-take-up. Whether this is a consequence of learning and adaptation processes, or due to a complete refusal of the system that led to nontake-up in the past, cannot be answered based on the data. Either way, it becomes clear that claiming old-age basic income support occurs less often among those who have no previous experience with means-based welfare systems.

To give a more thorough picture of the living situation of non-take-up households, table 2 also summarizes some proxies regarding the social situation. Overall, eligible households are less satisfied and socially embedded than non-eligible households, but at the same time, the social situation among those not claiming benefits is slightly better compared to the recipients.

Although the indicators available in GSOEP are not suitable for a straightforward causal analysis, a multivariate approach can substantiate the descriptive findings. Table 3 summarizes a logit analysis for the pooled data. The dependent variable has

9 This has partly changed in 2021. Personal allowances for the statutory pension in the basic income scheme have been introduced for people with long working careers.

10 Additional analysis shows that shorter periods of employment in the group of non-take-up households are mainly due to the lower labor market attachment of women in West Germany. 
Table 3

Logistic regression of non-take-up

\begin{tabular}{lrcc}
\hline Dep. Variable: non-take-up (0/1) & Logit & & SE \\
\hline East Germany (ref: West G.) & -1.246 & $* * *$ & 0.272 \\
Female (ref: male) & -0.380 & & 0.341 \\
Single household (ref: household > 1) & 0.283 & & 0.315 \\
Female*Single & 0.792 & + & 0.446 \\
Age & 0.077 & $*$ & 1.611 \\
Education (ref: low) & & & \\
$\quad$ medium & -0.081 & & 0.211 \\
$\quad$ high & 0.015 & & 0.309 \\
Need/income ratio & -3.423 & $* * *$ & 0.551 \\
Statutory Pension in 1000 $€$ & 0.960 & $* * *$ & 0.000 \\
Achievement orientation (0-7 high) & -0.025 & & 0.084 \\
Perception of financial stress & -0.290 & $* * *$ & 0.018 \\
Social isolation (0-4 very often) & -0.108 & & 0.094 \\
Life satisfaction(0-10 high) & -0.037 & & 0.053 \\
Exp. with means-tested benefits (ref: no) & -0.734 & $* *$ & 0.269 \\
Constant & -3.790 & $*$ & 1.611 \\
N & 758 & & \\
Pseudo R2 & & \\
Log Likelihood & 0.271 & & \\
\hline
\end{tabular}

Note: GSOEP 2010-2016, pooled data; robust standard errors; since the dependent variable refers to the previous year all independent variables are lagged; variable definitions: financial stress=index ranging from 0 to 3 , foregoing vacation and keeping old furniture for financial reasons increase the index by 1 as well as not having financial reserves; need/income ratio=basic income benefits (or simulated need)/net household income ranging from 0 to 1 ; for other variables see previous tables; level of significance: $+=p<0.1,{ }^{*}=p<0.05$, ${ }^{* *}=p<0.01,{ }^{* * *}=p<0.001$.

the value 0 for all recipients of basic income for old-age and 1 for all non-take-up households. Key variables from the descriptive analysis are included as independent variables. To take pooling into account, I use robust standard errors. The multivariate analysis supports the descriptive findings. Concerning the social structure, higher age leads to significantly higher chances of non-take-up, while living in East Germany increases the chances of take-up. Female-headed households do not show higher risks of non-take-up in general - although there is a tendency for higher non-takeup rates among women in single households, as the interaction effect indicates. As other studies have shown, especially widows have a high risk of non-take-up (Buslei et al. 2019). The educational level, in contrast, has no influence. To control financial incentives, which play a dominant role in rational choice explanations, a need/income ratio has been added to the model. The ratio takes values between zero and one and is calculated as the fraction of actual/simulated basic income benefits 
in relation to the household income. The coefficient shows that financial need is a relevant factor: The higher the share of (potential) basic income benefits, the lower is the probability of non-take-up. The payments of the statutory pension (acknowledgment hypothesis) play an important role, while at the same time, the attitudinal statement about achievement orientation has no influence. To measure the perception of financial stress due to material deprivation, the indicators included in table 2 have been combined. Following the coping argument, people who have no financial reasons to waive the yearly vacation or the replacement of old furniture, show a significantly lower probability for take-up. Social embeddedness does not influence non-take-up. In accordance with the descriptive findings, experiences with basic income support for unemployed in the past lead to a higher probability of take-up.

The last step takes a temporal perspective at the data to assess the dynamics of non-take-up and old-age basic income support. For older people, leaving the means-tested welfare scheme seems unlikely at first. There is little reason to expect major changes in their household structure and income situation that would result in surpassing the relevant financial thresholds for eligibility. Hence, abstracting from legislative changes, eligibility for old-age basic income support should be constant over time. In contrast, I argued in the theoretical section that the temporal dimension is part of individual strategies and therefore should be investigated empirically. If there are considerable dynamics, households may refrain from claiming benefits. To investigate this idea, all eligible households were monitored over the period from 2010 to 2015 (6 years). I examine to what extent households leave the status of (a) receiving benefits (b) not claiming benefits. Households changing their status during the period observed will also be further examined: How long have they been in this status and what happened after leaving? The sample consists of all households with at least two observations. A change of status is counted only if a new status can be observed. It should be noted that the results are very sensitive to potential survey errors and inaccuracies of the simulation. Thus, the results tend to overestimate the dynamics of the process.

Table 4 shows a considerable dynamic over time for both groups of eligible households. Between 2010 and 2015, $41 \%$ of all recipients of old-age basic income support leave the welfare system. The old-age basic income support does not seem to be a permanent state for many households. Most households that experience a status change stay only for a short time within the welfare system $(61 \%$ leave after one year). ${ }^{11}$ Most of the households that leave the means-tested scheme leave within the first two years. The high number of dropouts is surprising at first glance and is likely to be inflated by measurement errors. However, data from the official statistics also suggest a rather dynamic process over time with high numbers of dropouts. ${ }^{12}$

11 It must be noted that households receiving benefits in 2010 may have been receiving benefits in previous years. Therefore, the duration could be considerably higher.

12 Kaltenborn $(2019,192-193)$ analyzes the dropouts from old-age basic income support by using official statistics and shows that more than $10 \%$ of the recipients leave the welfare scheme each 
Table 4

Dynamics of old-age basic income support and Non-take-up over time

\begin{tabular}{lrr}
\hline & recipients & non-take-up \\
\hline \% without observed status change & 59.32 & 38.48 \\
\% with observed status change & 40.68 & 61.52 \\
n (households) & 177 & 382 \\
Status change after ... (in \%)* & & \\
1 year & 61.11 & 74.47 \\
2 years & 29.17 & 14.47 \\
3 years & 8.33 & 6.81 \\
$4-5$ years & 9.72 & 4.26 \\
n (households) & 72 & 235 \\
New status after status change (in \%) & & \\
$\quad$ Not-entitled & 86.11 & 95.74 \\
Recipients & - & 4.26 \\
Non-take-up & 13.89 & - \\
n (households) & 72 & 235 \\
\hline
\end{tabular}

Note: GSOEP 2011-2016 (6 years), unbalanced panel (2-6 observed episodes, $60 \%$ of households with $5 / 6$ episodes), households are grouped into: not-entitled, recipients, non-take-up on a yearly basis.

A closer look at the group of non-take-up households reveals that there is an even greater dynamic. Six out of ten households leave the status non-take-up during the period 2010 to 2015 . The majority (74\%) of these households were in nontake-up for only one year. The follow-up status reveals that non-take-up does not seem to be the result of a delayed transition period before claiming benefits - most of non-take-up households are later not eligible.

Overall, the results point to considerable dynamics of living situations in old age. Hence, current eligibility cannot predict eligibility in the future. But how could such dynamics be explained? To get a clearer picture of the dynamics during old age, a detailed analysis of income trajectories during retirement would be necessary. Such an analysis is out of scope for this article. However, a tentative exploration of the trajectories of eligible households indicates two main mechanisms: a) changes in the household structure (e.g. by death), b) a pension reform in 2014 which increased the pension income for mothers. Other factors that can be derived from the literature, e. g. reform of housing allowance (Kaltenborn 2019) or inheritance remain subject for further investigation. Regardless of the actual causes the find-

year (period 2015-2018). If mortality-related dropouts are excluded, still approx. $7 \%$ drop out annually. Official statistics also show that the duration of receiving benefits is often quite short although the length of stay is significantly longer than GSOEP-data suggests. Of all dropouts in $2017,20 \%$ received benefits for less than one year; another $23 \%$ leave the scheme after one up to three years (Kaltenborn 2019, 194). 
ings suggest that people may not claim benefits because they suppose their status of eligibility to be non-permanent.

\section{Concluding Remarks}

The phenomenon of non-take-up has been studied for many years. Despite clear evidence that non-take-up is widespread, it remains a niche-topic in social policy research. This seems to be unjustified since many people refrain from fundamental social rights, which raises serious questions about the legitimacy of the welfare state (Roosma et al. 2016). I have argued that stigma approaches as well as rational choice approaches help to understand non-take-up but leave room for questions. From a theoretical point of view, I have suggested going one step back and analyzing nontake-up from a relational perspective, with individual living situations on one side and institutionalized standards of normality on the other. To claim benefits, people must adapt to institutionalized normality to a certain extent.

The empirical results show that the number of people that do not claim benefits for old-age basic income support in Germany is higher (6 out of 10) than the number of recipients. A detailed analysis of their living situation reveals that non-take-up households suffer from a high degree of material deprivation that is comparable to the group of recipients. At the same time, they seem to cope with financial hardship much better. Despite comparable resources, non-take-up households feel less financial stress than recipients. Furthermore, non-take-up households rely heavily on entitlement-based benefits from the statutory pension. The missing acknowledgment of life-cycle achievements in means-tested programs may pose a serious burden for take-up. However, there is no high orientation towards former achievements on the attitudinal level. A more thorough analysis of the dimension of acknowledgment could enrich existing stigma-approaches by considering aspects beyond shame and social control. A longitudinal perspective reveals that there is a high dynamic over time. The simulation results suggest that only a minority belongs to the group of non-take-up for a long time. The household size, income, and expenses can, and do change over time. Hence, eligibility may also change. People likely consider potential changes before claiming benefits. However, these changes (e. g. household composition, inheritance, new sources of income) need further investigation.

How do these results relate to existing research? First and foremost, it must be stressed that the suggested relational perspective does not aim to replace existing approaches, but rather to supplement them. For example, stigma or process costs could be an underlying reason why coping is widespread. At the same time, there are good reasons to analyze non-take-up in a setting that relates individual actions to institutional norms. This opens the perspective for strategies of individuals in different living situations that often translate into non-take up. In this article, it 
has been shown that coping, acknowledgment, and the temporal perspective (CAT) are relevant.

Despite considerable theoretical and empirical efforts to study the phenomenon of non-take-up, the lack of adequate data remains a major problem. Surveys like GSOEP offer a comprehensive set of indicators necessary to simulate eligible households who are not claiming benefits. However, these surveys lack indicators that deal explicitly with possible reasons for non-take-up. A survey that combines both elements seems to be a promising starting point to study non-take-up more thoroughly. For Germany, there is only one older study based on the low-income panel (NIEP), which combines both elements (Becker and Hauser 2003). However, the NIEP was discontinued in 2002 and therefore only allows an analysis of the old system of social assistance (prior to major reforms). Furthermore, it seems to be promising to apply the relational framework proposed here in a qualitative study to widen the perspective of institutional and individual barriers for take-up. A different research question arises from the observed dynamics of households eligible for old-age basic income support. The empirical findings contradict the basic assumption of a fixed financial situation during retirement and should be analyzed in more detail.

\section{References}

Baumberg, Ben. 2016. The Stigma of Claiming Benefits: A Quantitative Study. Journal of Social Policy 45(2): 181-199.

Becker, Irene. 2012. Finanzielle Mindestsicherung und Bedürftigkeit im Alter. Zeitschrift für Sozialreform 58(2): 123-148.

Becker, Irene. 2016. Soziokulturelles Existenzminimum: Neuermittlung der Regelbedarfe nach altem Muster. Regelbedarfe müssten eigentlich wesentlich höher ausfallen. Soziale Sicherheit 65(12): 461-466.

Becker, Irene and Richard Hauser. 2003. Nicht-Inanspruchnahme zustehender Sozialhilfeleistungen (Dunkelzifferstudie). Universität Frankfurt, https://www.ssoar.info/ssoar/handle/document/32095 (13.08.2020).

Becker, Jens and Jennifer Gulyas. 2012. Armut und Scham - über die emotionale Verarbeitung sozialer Ungleichheit. Zeitschrift für Sozialreform 58(1): 83-100.

Bertrand, Marianne, Sendhil Mullainathan, and Eldar Shafir. 2006. Behavioral Economics and Marketing in Aid of Decision Making Among the Poor. Journal of Public Policy \& Marketing 25(1): 8-23.

Blomberg, Staffan and Jan Peterson. 2017. Stigma and Non-take up in Social Policy. Pp. 157-174 in Social Exclusion in Europe. Problems and Paradigms, edited by Paul Littlewood, Ignace Glorieux, and Ingrid Jönsson. New York: Routledge.

Bruckmeier, Kerstin and Jürgen Wiemers. 2018. Benefit Take-Up and Labor Supply Incentives of Interdependent Means-Tested Benefit Programs for Low-Income Households. Comparative Economic Studies 60(4): 583-604.

Bruckmeier, Kerstin, Regina T. Riphahn, and Jürgen Wiemers. 2020. Misreporting of Program Take-Up in Survey Data and Its Consequences for Measuring Non-Take-Up: New Evidence From Linked Administrative and Survey Data. Empirical Economics 91, https://doi.org/10.1007/s00181-02001921-4 (19.10.2020) 
Bullock, Heather E., Karen Fraser Wyche, and Wendy R. Williams. 2001. Media Images of the Poor. Journal of Social Issues 57: 229-246.

Buslei, Hermann, Johannes Geyer, Peter Haan, and Michelle Harnisch. 2019. Wer bezieht Grundsicherung im Alter? - Eine empirische Analyse der Nichtinanspruchnahme. FNA-Journal 4, https:// www.fna-rv.de/subsites/FNA/de/Inhalt/97_Allgemeines/Downloads/FNA/FNA-Journal/FNAJournal-2019-04.pdf?__blob=publicationFile\&v=3 (13.08.2020).

Currie, Janet. 2006. The Take-Up of Social Benefits. Pp. 80-148 in Public Policy and the Income Distribution, edited by Alan J. Auerbach, David Card, and John M. Quigley. New York: Russell Sage Foundation.

Dubois, Hans and Anna Ludwinek. 2015. Access to Social Benefits: Reducing Non-Take-Up. Eurofound, https://www.eurofound.europa.eu/sites/default/files/ef_publication/field_ef_document/ef1536en. $\operatorname{pdf}(13.08 .2020)$.

Elias, Norbert. 2013. Über den Prozeß der Zivilisation - Zweiter Band. Frankfurt/Main: Suhrkamp.

Engelhardt, Michael von. 2010. Erving Goffman: Stigma. Über Techniken der Bewältigung beschädigter Identität. Pp. 123-140 in Schlüsselwerke der Identitätsforschung, edited by Benjamin Jörissen, and Jörg Zirfas. Wiesbaden: VS Verlag für Sozialwissenschaften.

Frick, Joachim R. and Olaf Groh-Samberg. 2007. To Claim or Not to Claim: Estimating Non-Take-Up of Social Assistance in Germany and the Role of Measurement Error, SOEPpapers. DIW, https:// www.diw.de/documents/publikationen/73/diw_01.c.73264.de/dp734.pdf (13.08.2020).

Goebel, Jan, Markus M. Grabka, Stefan Liebig, Martin Kroh, David Richter, Carsten Schröder, and Jürgen Schupp. 2019. The German Socio-Economic Panel (SOEP). Journal of Economics and Statistics 239(2): 345-360.

Goffman, Erving. 1990. Stigma. London: Penguin.

Gurr, Thomas and Monika Jungbauer-Gans. 2017. Eine Untersuchung zu Erfahrungen Betroffener mit dem Stigma Arbeitslosigkeit. Soziale Probleme 28(1): 25-50.

Harnisch, Michelle. 2019. Non-Take-Up of Means-Tested Social Benefits in Germany. DIW Discussion Papers 1793, https://www.diw.de/documents/publikationen/73/diw_01.c.616586.de/dp1793. pdf (13.08.2020).

Hernanz, Virginia, Franck Malherbet, and Michele Pellizzari. 2004. Take-Up of Welfare Benefits in OECD Countries: A Review of the Evidence. OECD Social, Employment and Migration Working Papers, https://www.oecd-ilibrary.org/take-up-of-welfare-benefits-in-oecd-countries_5lgsjhvj7pd3. pdf?itemId=\%2Fcontent $\% 2$ Fpaper\%2F525815265414\&mimeType=pdf (13.08.2020).

Hümbelin, Oliver. 2019. Non-Take-Up of Social Assistance: Regional Differences and the Role of Social Norms. Swiss Journal of Sociology 45(1): 7-33.

Kaltenborn, Bruno. 2019. Grundsicherung im Alter und bei Erwerbsminderung: Ein statistisches Kompendium. DRV-Schriften.

Kayser, Hilke and Joachim R. Frick. 2001. Take it or Leave it: (Non-)Take-Up Behavior of Social Assistance in Germany. Schmollers Jahrbuch 121(1): 27-58.

Kerr, Scott A. 1982. Deciding About Supplementary Pensions: A Provisional Model. Journal of Social Policy 11(4): 505-517.

Mika, Tatjana and Ulrich Bieber. 2006. Verdeckte Armut der älteren Bevölkerung. Ausmaß von Niedrigeinkommen und Gründe der Nichtinanspruchnahme von Sozialhilfe unter Senioren. Deutsche Rentenversicherung 4/5: 248-279.

Moffitt, Robert. 1983. An Economic Model of Welfare Stigma. American Economic Review 73(5): 1023-1035.

Neuenschwander, Peter, Oliver Hümbelin, Marc Kalbermatter, and Rosmarie Ruder. 2012. Der schwere Gang zum Sozialdienst. Zürich: Seismo-Verlag.

Offe, Claus. 1984. Contradictions of the Welfare State. London: Hutchinson. 
Riphahn, Regina T.. 2001. Rational Poverty or Poor Rationality? The Take-Up of Social Assistance Benefits. Review of Income and Wealth 47(3): 379-398.

Roosma, Femke, Wim van Oorschot, and John Gelissen. 2016. The Achilles' Heel of Welfare State Legitimacy: Perceptions of Overuse and Underuse of Social Benefits in Europe. Journal of European Public Policy 23(2): 177-196.

Saraceno, Chiara, 2002: Social Assistance Dynamics in Europe: National and Local Poverty Regimes. Bristol: Policy Press.

Simmel, Georg. 2009[1908]. Sociology: Inquiries into the Construction of Social Forms. Leiden/Boston: Brill.

Simon, Herbert A. 1997. Models of Bounded Rationality: Empirically Grounded Economic Reason. Cambridge: MIT press.

Steiner, Viktor, Katharina Wrohlich, Peter Haan, and Johannes Geyer. 2012. Documentation of the Tax-Benefit Microsimulation Model STSM. DIW Data Documentation, DIW, https://www.diw. de/documents/publikationen/73/diw_01.c.394794.de/diw_datadoc_2012-063.pdf(13.08.2020).

Van Lancker, Wim, Helene Cappelle, Nele Cox, Ann Decorte, Evelien Defossez, Hanne Denoo, Frank Stevens, and Anna Willems. 2020. Mobile Integrated Social Services Increasing Employment Outcomes for People in Need, https://www.kortrijk.be/sites/kortrijk/files/2020-03/MISSION_FINAL\%20 REPORT.pdf (13.08.2020).

Van Mechelen, Natascha and Julie Janssens. 2017. Who is to Blame? An Overview of the Factors Contributing to the Non-take-up of Social Rights. Herman Deleeck Centre for Social Policy Working Paper, https://takeproject.files.wordpress.com/2017/12/van-mechelen_janssens_2017.pdf (13.08.2020).

Van Oorschot, Wim. 1998. Failing Selectivity: On the Extent and Causes of Non-take-up of Social Security Benefits. Pp. 101-130 in Empirical Poverty Research in a Comparative Perspective, Aldershot: Ashgate.

Van Oorschot, Wim. 2002. Targeting Welfare: On the Functions and Dysfunctions of Means-testing in Social Policy. Pp. 171-193 in World Poverty: New Policies to Defeat an Old Enemy, edited by Peter Townsend, and David Gordon. Bristol: Policy Press.

Vobruba, Georg. 2000. Alternativen zur Vollbeschäftigung. Frankfurt/Main: Suhrkamp.

Vobruba, Georg. 2002. Actors in Processes of Inclusion and Exclusion: Towards a Dynamic Approach. Social Policy \& Administration 34(5): 601-613.

Voges, Wolfgang and Melanie Zinke. 2010. Wohnen im Alter. Pp. 301-308 in Handbuch Soziale Arbeit und Alter, edited by Kirsten Aner, and Ute Karl. Wiesbaden: Springer.

Walker, Robert. 2014. The Shame of Poverty. Oxford: Oxford University Press.

Whelan, Stephen. 2010. The Take-Up of Means-Tested Income Support. Empirical Economics 39(3): $847-875$.

Wilke, Felix. 2016. Sparen für unsichere Zeiten. Die schwierige Organisation privater Altersvorsorge. Wiesbaden: Springer VS. 